\title{
Mind the gap: task design and technology in novice language teachers' practice
}

\author{
Tom F. H. Smits ${ }^{1}$, Margret Oberhofer ${ }^{2}$, and Jozef Colpaert ${ }^{3}$
}

\begin{abstract}
This paper focuses on the possibilities/challenges for English as a Foreign Language (EFL) teachers designing tasks grounded in Task-Based Language Teaching (TBLT) and taking advantage of the affordances of technology - Interactive WhiteBoards (IWBs). Teachers have been shown to confuse tasks with exercises or activities. The interactive Technologies in Language Teaching (iTILT) projects revealed that when it comes to IWB use the focus often shifts from interactive teaching to interactive technology. To better prepare novice EFL teachers for their future teaching practice, an 'IWB for TLBT' training programme introduced the affordances of IWBs. Our analysis of how (un)successful they were at marrying TBLT and Information and Communication Technology (ICT) operationalised TBLT criteria from Nunan (2004) and Erlam (2016). Supporting evidence of the participants' aptitude in TBLT practice is provided by a traditional, non-IWBoriented task each individual had designed earlier. Combining both elements in the analysis, our study answers the question: to what extent are pre-service teachers able to design a TBLT environment involving modern technology that adheres to iTILT principles and current theories of TBLT methodology?
\end{abstract}

Keywords: TBLT, task design, EFL, IWB, teacher education.

\section{Introduction}

The objective of the European interactive Teaching In Languages with Technology (iTILT2) project, launched in 2014, is to explore the affordances of devices like smartphones and IWBs. More specifically, it investigates the effective use of

\footnotetext{
1. Universiteit Antwerpen, Antwerp School of Education, Antwerpen, Belgium; tom.smits@uantwerp.be 2. Universiteit Antwerpen, Antwerpen, Belgium; margret.oberhofer@uantwerp.be

3. Universiteit Antwerpen, Antwerpen, Belgium; jozef.colpaert@uantwerp.be
}

How to cite this article: Smits, T. F. H., Oberhofer, M., \& Colpaert, J. (2016). Mind the gap: task design and technology in novice language teachers' practice. In S. Papadima-Sophocleous, L. Bradley \& S. Thouësny (Eds), CALL communities and culture - short papers from EUROCALL 2016 (pp. 429-434). Research-publishing.net. https://doi.org/10.14705/rpnet.2016. eurocall2016.601 
these interactive technologies within a TBLT approach. iTILT2 builds on, and extends, the EU project iTILT, focusing on IWBs for teaching foreign languages. However, iTILT2 moves beyond IWBs and includes effective educational design for foreign language learning with a wider range of new interactive technologies (tablets, laptops, mobile phones, videoconferencing software). The educational contexts vary from primary and secondary schools to vocational colleges and universities.

TBLT theory is central to ITILT2 and requires students to do meaningful tasks in the target language, having to choose for themselves the linguistic means for task completion. A task is "an activity in which people engage to attain an objective and which involves the meaningful use of language" (Van den Branden, Van Gorp, \& Verhelst, 2007, p. 1). An objective can be anything from producing a poster or website to expressing opinions or writing song lyrics. As learning the target language means making use of it, learners are primarily seen as language users.

Research shows that many language teachers find it difficult to distinguish tasks from simple grammar exercises or activities for vocabulary practice. To help teachers, Shintani (2013) discussed the principles behind TBLT and outlined the main features of language learning tasks:

1. activity focus is on meaning, i.e. learners encode/decode messages, no grammar or vocabulary drilling;

2. communicative/information gap, e.g. learners need to ask for information they do not have (= gap) or need to express their opinion;

3. learners draw on their own (linguistic/non-linguistic) resources to complete tasks. They are not 'taught' the language nor the form to use to complete the task but are free to choose their 'means', although they could for example borrow from the input, use dictionaries/online resources, ask the teacher, etc.);

4. clearly defined outcomes other than mere language use, e.g. poster, form, handout, opinion, or reaching a compromise in discussions. While "performing a task, learners are not primarily concerned with using the language correctly but rather achieving the goal stipulated within the task" (Ellis, 2003, p. 35). 


\section{Method}

\subsection{Dataset}

Our study goes beyond Erlam's (2016) by not limiting itself to applying criteria for task design (e.g. from Ellis, 2003, in Erlam's (2016) study) to evaluate foreign language teachers' self-made TBLT materials in a professional development programme; we also consider the conception of a task in the minds of (postgraduate) pre-service foreign language teachers $(\mathrm{N}=28)$ by analysing a design task that had them formulate a taaltaak (integrated language/assessment task). Consequently, the dataset exists of (1) materials designed for use with the IWB, part of (the evaluation of) a series of lessons on TBLT, and (2) the somewhat more traditional taaltaken.

The latter tasks the participants designed before the IWB technology was introduced had to contain a step-by-step description with process and product requirements for one or more open-ended B1 tasks fostering the autonomous use of (a) language skill(s) in an authentic context. The choices student teachers made when designing these tasks revealed what they consider meaningful language use for learning and/ or open communicative contexts.

Each set of IWB TBLT materials (i.e. the aforementioned (1)) consisted of a lesson plan and the TBLT materials for the IWB (Smarttech Notebook ${ }^{\circledR}$ ). The assignment required student duos to plan a lesson on a cultural topic with B1 TBLT activities involving the IWB and to develop accompanying materials.

\subsection{Data analysis}

The criteria to analyse the pre-service teachers' TBLT approach and materials against were inspired by Nunan's (2004) aspects of qualitative task design: task objective, input quality, quality of activities, classroom setting, and teacher and learner roles.

Given our study's affinities with Erlam (2016), an evaluation grid was used that is based on the central features of TBLT in Nunan's (2004) paradigm and includes some of Erlam's (2016) task criteria (Table 1). The lesson material suits (min. three task slides) were independently evaluated by the first and second author (inter-rater reliability). 
Table 1. Task evaluation grid

\begin{tabular}{|l|l|l|}
\hline 1. Meaning versus form & (yes) 1/0.5/0 (no) & $\begin{array}{l}\text { Comments/ } \\
\text { Justifications }\end{array}$ \\
\hline $\begin{array}{l}\text { Are pupils acting as language } \\
\text { users (rather than learners)? }\end{array}$ & & \\
\hline $\begin{array}{l}\text { Are pupils mainly concerned with } \\
\text { expressing/comprehending meaning } \\
\text { (not focusing on form)? }\end{array}$ & & \\
\hline 2. Information gap & & \\
\hline $\begin{array}{l}\text { Do pupils close an information gap as a } \\
\text { result of communication taking place? }\end{array}$ & & \\
\hline $\begin{array}{l}\text { Do pupils find out something they did not } \\
\text { know as a result of the communication? }\end{array}$ & & \\
\hline 3. Learner resources & & \\
\hline $\begin{array}{l}\text { Has not all language needed for the } \\
\text { task been specially pre-taught? }\end{array}$ & & \\
\hline $\begin{array}{l}\text { Does the task allow learners to use language } \\
\text { learnt on other, unrelated occasions? }\end{array}$ & & \\
\hline 4. Result/outcome & & \\
\hline $\begin{array}{l}\text { Do pupils use English to achieve an } \\
\text { outcome (not as an end in itself)? }\end{array}$ & & \\
\hline $\begin{array}{l}\text { Do pupils have to achieve a result to } \\
\text { demonstrate task completion? }\end{array}$ & & \\
\hline 5. Technology use & & \\
\hline $\begin{array}{l}\text { Is the use of technology integral to the task } \\
\text { design? (Is it impossible to do the task } \\
\text { without technology, not just more difficult?) }\end{array}$ & \\
\hline $\begin{array}{l}\text { Does the technology have added } \\
\text { pedagogical value (not just motivational)? }\end{array}$ & & \\
\hline
\end{tabular}

\section{Discussion}

With an $M$ score of $6.375 / 10(S D=1.398)$, it cannot be claimed that all participants were successful at applying the programme's input in practice. Of the 14 IWB lesson designs, two were rated unsatisfactory, two achieved the highest score of $9 / 10$. Zooming in on the task design criteria, the trainee teachers struggled most with the TBLT 'Information gap' element (No. 2 in the grid): utilising communication to close an information gap $(M=0.429)$ and allowing pupils to find out something new $(M=0.571)$. 'Meaning vs form' (No. 1) and 'Learner resources' (No. 3) were the aspects they performed best on. Having learners mainly concerned with expressing and comprehending meaning (instead of focusing on form) appears to have been easiest to achieve $(M=0.833)$. Discussing 
further results would go beyond the scope of this short paper, but the study's practice-based output allows for fine-tuning of the criteria (within the iTILT2 project) so that researchers will have better tools to analyse the TBLT approach of (novice) teachers, and the teachers themselves a clearer idea of what sound TBLT requires.

A Pearson's $r$ hypothesis test did not reveal a (significant) correlation between the IWB group assignment and the individual classic task design $(\mathrm{r}=-0.105, \mathrm{n}=7$, $\mathrm{p}=0.6084$ ) that was to demonstrate causality between TBLT comprehension and task design quality. This does imply, however, that the pre-service teachers benefited from the collaborative aspect of the IWB assignment (and/or from the 'IWB for TBLT' programme itself) and - we would like to think - from the affordances of technology to facilitate meaningful, realistic tasks in class.

\section{Conclusions}

The effect of TBLT can be increased considerably, but besides specific affordances, using new technologies like IWBs also entails constraints. From our study and our broader experience with technology, we infer four hypotheses.

1. Tasks should be made more motivating by focusing on their mental acceptability and students' willingness to carry them out. Meaningfulness ('What's in it for me?') and usefulness ('What's in it for others?') are key concepts in this respect.

2. Tasks should be seen within a wide range of possible activities, from simple drill-and-practice exercises to co-construction of knowledge. Bloom's Digital Taxonomy (Churches, 2009), the SAMR model (Romrell, Kidder, \& Wood, 2014) or 21st Century Skills can be inspiring in this respect.

3. There is too much focus on the properties of the task as a product, and not enough on task design as a process: how to select and adapt tasks to the specific and variable context of language learners and teachers.

4. Tasks should always be seen as hypotheses. The validation of these hypotheses should be carried out by comparing the expected outcome with the actual outcome. 


\section{Acknowledgements}

iTILT2, funded by Erasmus Plus programme (2014-17), focuses on mobile technologies and language learning; http://www.itilt2.eu. iTILT, funded by Lifelong Learning Programme (KA2 Languages, 2011-13), focused on IWBs for FLT; www.itilt.eu.

\section{References}

Branden, K. Van den, Gorp, K. Van, \& Verhelst, M. (2007). Tasks in action: task-based language education from a classroom-based perspective. In K. Van den Branden, K. Van Gorp, \& M. Verhelst (Eds), Tasks in action. task-based language education from a classroom-based perspective (pp. 1-6). Newcastle: Cambridge Scholars Publishing.

Churches, A. (2009). Bloom's digital taxonomy; educational origamy. http://edorigami. wikispaces.com/Bloom's+Digital+Taxonomy

Ellis, R. (2003). Task-based language learning and teaching. Oxford: Oxford University Press.

Erlam, R. (2016). 'I'm still not sure what a task is': teachers designing language tasks. Language Teaching Research, 20(3), 279-299. https://doi.org/10.1177/1362168814566087

Nunan, D. (2004). Task-based language teaching. Cambridge: Cambridge University Press. https://doi.org/10.1017/CBO9780511667336

Romrell, D., Kidder, L. C., \& Wood, E. (2014). The SAMR model as a framework for evaluating mLearning. Journal of Asynchronous Learning Networks, 18(2), 1-15.

Shintani, N. (2013). Using tasks with young beginner learners: the role of the teacher. Innovation in Language Learning and Teaching, 8(3), 279-294. https://doi.org/10.1080/ 17501229.2013 .861466 


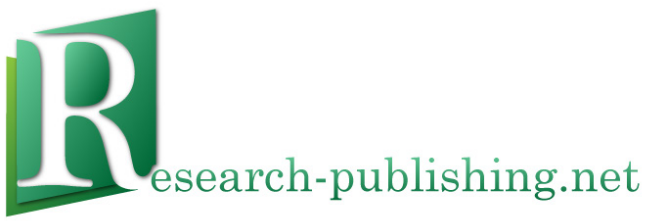

Published by Research-publishing.net, not-for-profit association Dublin, Ireland; Voillans, France, info@research-publishing.net

(C) 2016 by Editors (collective work)

(C) 2016 by Authors (individual work)

\section{CALL communities and culture - short papers from EUROCALL 2016 Edited by Salomi Papadima-Sophocleous, Linda Bradley, and Sylvie Thouësny}

Rights: All articles in this collection are published under the Attribution-NonCommercial -NoDerivatives 4.0 International (CC BY-NC-ND 4.0) licence. Under this licence, the contents are freely available online as PDF files (https://doi. org/10.14705/rpnet.2016.EUROCALL2016.9781908416445) for anybody to read, download, copy, and redistribute provided that the author(s), editorial team, and publisher are properly cited. Commercial use and derivative works are, however, not permitted.

\section{(9) $\Theta \Theta$}

Disclaimer: Research-publishing.net does not take any responsibility for the content of the pages written by the authors of this book. The authors have recognised that the work described was not published before, or that it is not under consideration for publication elsewhere. While the information in this book are believed to be true and accurate on the date of its going to press, neither the editorial team, nor the publisher can accept any legal responsibility for any errors or omissions that may be made. The publisher makes no warranty, expressed or implied, with respect to the material contained herein. While Research-publishing.net is committed to publishing works of integrity, the words are the authors' alone.

Trademark notice: product or corporate names may be trademarks or registered trademarks, and are used only for identification and explanation without intent to infringe.

Copyrighted material: every effort has been made by the editorial team to trace copyright holders and to obtain their permission for the use of copyrighted material in this book. In the event of errors or omissions, please notify the publisher of any corrections that will need to be incorporated in future editions of this book.

Typeset by Research-publishing.net

Cover design by (C) Easy Conferences, info@easyconferences.eu,www.easyconferences.eu

Cover layout by (c) Raphaël Savina (raphael@savina.net)

Photo "bridge" on cover by (C) Andriy Markov/Shutterstock

Photo "frog" on cover by (C) Fany Savina (fany.savina@gmail.com)

Fonts used are licensed under a SIL Open Font License

ISBN13: 978-1-908416-43-8 (Paperback - Print on demand, black and white)

Print on demand technology is a high-quality, innovative and ecological printing method; with which the book is never 'out of stock' or 'out of print'.

ISBN13: 978-1-908416-44-5 (Ebook, PDF, colour)

ISBN13: 978-1-908416-45-2 (Ebook, EPUB, colour)

Legal deposit, Ireland: The National Library of Ireland, The Library of Trinity College, The Library of the University of Limerick, The Library of Dublin City University, The Library of NUI Cork, The Library of NUI Maynooth, The Library of University College Dublin, The Library of NUI Galway.

Legal deposit, United Kingdom: The British Library.

British Library Cataloguing-in-Publication Data.

A cataloguing record for this book is available from the British Library.

Legal deposit, France: Bibliothèque Nationale de France - Dépôt légal: décembre 2016. 